Piwulang 7 (2)(2019)
Teaching
http://journal.unnes.ac.id/sju/index.php/piwulang

\title{
APLIKASI 'JAJANANKU' SEBAGAI SISTEM INFORMASI JAJANAN TRADISIONAL SE-KARESIDENAN KEDU BERBASIS ANDROID BERDASARKAN KAJIAN FOLKLOR
}

\author{
Arif Nugroho \\ Jurusan Bahasa dan Sastra Jawa, Fakultas Bahasa dan Seni, Universitas Negeri Semarang, Indonesia \\ Corresponding Author: arifnugro9@gmail.com
}

\begin{abstract}
Abstrak
Penelitian ini bertujuan menjelaskan jajanan yang visibel, mendeskripsikan cara kerja purwarupa, dan mendeskripsikan bentuk purwarupa aplikasi Jajananku sebagai sistem informasi jajanan tradisional se-Karesidenan Kedu berbasis android berdasarkan kajian folklor. Penelitian ini merupakan penelitian Research and Development (R\&D) dengan teknik deskriptif kualitatif. Sasaran penelitian ini adalah terciptanya aplikasi Jajananku sebagai sistem informasi jajanan tradisional se-Karesidenan Kedu berbasis android berdasarkan kajian folklor. Simpulan dari penelitian ini adalah, pertama terdapat lima puluh jajanan tradisional yang visibel yang dikaji berdasarkan kajian folklor dan dimuat dalam aplikasi Jajananku. Kedua, cara kerja aplikasi Jajananku dapat dengan mudah dijalankan dan alur rancang bangun sesuai dengan harapan peneliti sehingga aplikasi mudah dioperasikan. Ketiga, aplikasi Jajananku dapat diakses oleh platform minimal pada sdk Ice Cream Sandwich (ICS) dengan ukuran 7Mb dan berisikan informasi tentang jajanan tradisional berdasarkan kajian folklor.
\end{abstract}

Kata Kunci: android, aplikasi, jajanan tradisional, kajian folklor, sistem informasi

\begin{abstract}
This research aims at explaining the variety of visible tidbits and describing the mechanism of the said application's prototype as an information system of traditional tidbits in the area of Kedu in android platform. This research is of Research and Development $(R \& D)$ type with descriptive qualitative technique. The target of this research is to optimally utilize the Jajananku application as an information system of traditional tidbits in the area of Kedu in android platform based on folklore study. There are three conclusions deducted from this research. First, there are fifty visible traditional tidbits studied in folklore base and are available in the Jajananku application. Second, the mechanism of the Jajananku application can be easily operated as its design plot has met the research's target. Third, this application can be accessed in android platform starting from Ice Cream Sandwich (ICS) sdk (software development kit) with $7 M B$ in size containing information abaut traditional tidbits based on folklore study.
\end{abstract}

Keywords: application, information system, traditional tidbits, android, folklore study

(C) 2019 Universitas Negeri Semarang

p-ISSN 2252-6307

e-ISSN 2714-868x 
Arif Nugroho/ Piwulang 7 (2) (2019)

\section{PENDAHULUAN}

Seiring perkembangan jaman, gawai atau khususnya smartphone semakin diminati dan sebagian besar elemen masyarakat menggunakan perangkt tersebut. Smartphone yang semakin canggih mampu mengakses berbagai situs dalam internet, hal ini memudahkan masyarakat untuk mendapatkan segala macam informasi. Kemudahan-kemudahan ini memberikan dampak kepada masyarakat pada umumnya dan khususnya pengguna smartphone baik positif maupun negatif.

Melihat dampak yang kita rasakan saat ini membuat peneliti ingin memanfaatkan kemudahan teknologi dengan baik, benar, dan bertanggungjawab. Salah satu cara pemanfaatan teknologi yang ingin diterapkan peneliti adalah dengan mengombinasikan dengan produk budaya. Salah satu produk budaya yang ingin peneliti kombinasikan dengan teknologi adalah makanan tradisional.

Peneliti yang berasal dari Kabupaten Temanggung ingin menggali informasi mengenai jajanan tradisional di daerah sekitar tempat tinggal peneliti dengan pertimbangan tertentu. Hasil penelitian nanti akan dijadikan materi yang dapat diakses menggunakan perangkat smartphone. Kemudian untuk menyesuaikan penelitian dengan bidang studi peneliti, ada dua bidang studi yang memungkinkan untuk dijadikan dasar penelitian berkaitan dengan makanan tradisional yaitu etnolinguistik dan folklor atau sastra lisan. Kemudian melihat dari kebutuhan penelitian, maka peneliti memilih kajian folklor sebagai dasar penelitian.
Makanan merupakan sebuah folklor bukan lisan sub kelompok material dan dari genre makanan rakyat karena dari bentuknya makanan bukanlah berbentuk lisan, tetapi cara pembuatannya diajarkan secara lisan. Makanan merupakan foklor bukan lisan. Salah satu ciri-ciri utama pengenal folklor adalah penyebaran dan pewarisannya dilakukan dari mulut ke mulut atau melalui tutur/lisan, disebarkan relatif tetap atau dalam bentuk standar. Disebarkan di antara lokasi tertentu dalam waktu yang cukup lama, ada dalam bentuk versi-versi, bersifat anonim, menjadi milik bersama (Danandjaya, 2007: 3-4). Bila ditiilk dari ciri-ciri pengenal tersebut, maka makanan rakyat maupun makanan tradisional keraton termasuk ke dalam folklor. Istilah makanan tradisional dipilih dalam tulisan ini karena mempunyai cakupan makna yang lebih luas. Makanan dalam kajian folklore dibahas menjadi 1; cara memperoleh makanan, 2; cara pengolahan makanan, 3; cara penyajian, dan 4; fungsi makanan.

Sistem informasi adalah suatu sistem di dalam suatu organisasi yang mempertemukan kebutuhan pengelolaan transaksi harian, mendukung operasi, bersifat manajerial, dan kegiatan strategi dari suatu organisasi dan menyediakan pihak luar tertentu dengan laporanlaporan yang dibutuhkan (Hutahean, 2014: 8). Android (/æn.droid/; an-droyd) adalah sistem operasi berbasis Linux yang dirancang untuk perangkat bergerak layar sentuh seperti telepon pintar dan komputer tablet (Wikipedia, 2017).

Setelah didapatkan alasan yang sesuai dengan kebutuhan penelitian, kemudian peneliti ingin membuat sebuah sistem informasi yang 
Arif Nugroho/ Piwulang 7 (2) (2019)

berkaitan dengan teknologi dan dapat memuat materi atau informasi mengenai jajanan tradisional dengan kajian folklor. Sistem informasi yang ingin peneliti buat adalah sebuah aplikasi berbasis android yang mudah diakses dan digunakan. Aplikasi berisikan jajanaan maupun makanan tradisional sudah ada yang membuatnya, tetapi isi dari aplikasi yang dibuat hanya terbatas pada daerah, resep, dan cara pembuatannya saja. Aplikasi yang dikembangkan oleh peneliti diharapkan memiliki keunggulan dari aplikasi yang sudah ada. Berdasarkan kajian folklor isi atau muatan dalam aplikasi yang dikembangkan peneliti tidak hanya sebatas resep dan cara pembuatan, melainkan ada bahan baku utama, resep, cara pembuatan, cara penyajian, dan fungsi makanan.

Uraian yang telah peneliti paparkan melatarbelakangi perancangan Aplikasi 'Jajananku' sebagai Sistem Informasi Jajanan Tradisional se-Karesidenan Kedu Berbasis Android Berdasarkan Kajian Folklor. Perancangan aplikasi ini didasari oleh kebutuhan masyarakat terhadap informasi mengenai jajanan tradisional Jawa Tengah. Peneliti melakukan pengembangan berupa membuat prototipe sistem informasi mengenai jajanan tradisional dalam sebuah aplikasi android. Sistem ini bertujuan agar masyarakat umum dan khususnya masyarakat Jawa Tengah dapat lebih mengenal dan mengetahui aneka ragam jajanan tradisional seKaresidenan Kedu. Sistem ini diwujudkan dalam sebuah aplikasi berbasis android dengan konsep dwibahasa, yaitu bahasa Jawa ragam ngoko dan bahasa Indonesia. Berdasarkan permasalahan di atas, rumusan masalah penelitian ini adalah sebagai berikut : (1) Apa saja jajanan yang visibel dalam aplikasi Jajananku berdasarkan kajian folklor? (2) Bagaimana cara kerja prototipe aplikasi Jajananku sebagai sistem informasi jajanan tradisional se-Karesidenan Kedu berbasis android berdasarkan kajian folklor? (3) Bagaimana bentuk prototipe aplikasi Jajananku sebagai sistem informasi jajanan tradisional seKaresidenan Kedu berbasis android berdasarkan kajian folklor?

\section{METODE PENELITIAN}

Penelitian ini merupakan penelitian pengembangan atau Research and Development (R\&D). Desain ini digunakan untuk menghasilkan produk dan menguji keefektifan produk (Sugiyono, 2013: 407). Langkah-langkah dalam pengembangan penelitian adalah sebagai berikut; (1) potensi dan masalah, (2) Pengumpulan data, (3) desain produk, (4) validasi desain, (5) revisi desain, (6) uji coba produk, (7) revisi produk, (8) uji coba pemakaian, (9) revisi produk, dan (10) produksi massal.

Namun, dalam penelitian ini dilakukan penyederhanaan langkah menjadi lima. Langkah ini diambil untuk menyesuaikan dengan kebutuhan penelitian, waktu penelitian dan tujuan penelitian berupa pengembangan aplikasi yang berisi informasi jajanan tradisional. Adapun lima langkah penelitian yang akan dilakukan adalah analisis potensi dan masalah, analisis kebutuhan, desain produk, validasi desain, dan revisi desain.

Untuk mendapatkan data yang sesuai dengan kebutuhan, maka peneliti harus 
menentukan sasaran penelitian agar data tetap fokus, terarah, dan sesuai. Peneliti menentukan sasaran penelitian, yaitu terciptanya aplikasi 'Jajananku' sebagai sistem informasi jajanan tradisional se-Karesidenan Kedu berbasis android berdasarkan kajian folklor. Berdasarkan sasaran penelitian di atas, maka subjek penelitian ini adalah masyarakat ahli jajanan baik yang memproduksi maupun yang mengerti jajanan tradisional se-Karesidenan Kedu. Untuk kevalidan data peneliti merujuk ke tiga pakar ahli, yaitu ahli tata boga, ahli folklor, dan ahli IT.

Teknik pengumpulan data penelitian ini menggunakan teknik wawancara. Teknik wawancara meliputi, wawancara terstruktur dan tidak tersetruktur. Teknik angket meliputi, angket kebutuhan yang dilakukan pada awal sebelum penelitian dan angket validasi desain atau uji ahli. Kedua teknik digunakan untuk memperoleh data dan informasi dalam penelitian pembuatan aplikasi sistem informasi jajanan tradisonal seKaresidenan Kedu berdasarkan kajian folklor.

Analisis data adalah proses mencari dan menyusun secara sistematis data yang diperoleh dari hasil wawancara, catatan lapangan dan dokumentasi, dengan cara mengorganisasikan data ke dalam kategori, menjabarkan ke dalam unit-unit, melakukan sintesa, menyusun ke dalam pola, memilih mana yang penting dan yang akan dipelajari, dan membuat kesimpulan sehingga mudah difahami diri sendiri maupun orang lain (Sugiyono, 2013: 335). Teknik analisis data penelitian ini menggunakan satu teknik analisis, yaitu teknik analisis data yang visibel untuk purwarupa (prototipe).
Penelitian ini menggunakan bentuk instrumen nontes yang berupa pedoman wawancara, angket kebutuhan, dan angket validasi desain atau uji ahli. Instrumen penelitian digunakan untuk memperoleh data serta informasi yang berperan penting dalam proses pembuatan produk. Adapun instrumen penelitian untuk pembuatan aplikasi Jajananku sebagai suatu sistem informasi jajanan tradisional seKaresidenan Kedu berbasis android adalah pedoman wawancara dan angket kebutuhan.

\section{HASIL DAN PEMBAHASAN}

\section{Jajanan yang Visibel dalam Kajian Folklor}

Penelitian ini dilakukan di lima Kabupaten seKaresidenan Kedu, meliputi Kabupaten Temanggung, Kabupaten Wonosobo, Kabupaten Magelang, Kabupten Purworejo, dan Kabupaten Kebumen. Peneliti mengambil data dari beberapa sumber, yaitu pasar tradisional, penjual jajanan keliling, dan pembuat jajanan.

Emping Jet

Genre : Jajanan tradisional

Daerah asal : Temanggung

Suku bangsa : Suku Jawa

Peneliti mengambil data produk dan data informasi di rumah pembuat sekaligus penjual emping jet, yaitu Ibu Kuwati (60 tahun), alamat: Jubug, RT/RW 02/02, Wanutengah, Parakan, Temanggung. Kegiatan pengambilan data informasi berada di rumah Ibu Kuwati, ketika pengambilan data ada beberapa orang yang berada di lokasi, yaitu Pak Jupri suami Ibu Kuwati, Ari putra Ibu Kuwati, dan istri dari kakak Ari. 
Arif Nugroho/ Piwulang 7 (2) (2019)

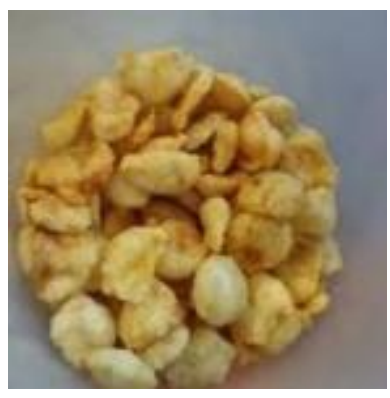

Gambar 1. Emping Jet

Emping jet adalah jajanan yang memiliki rasa gurih. Emping jet memiliki bentuk seperti emping namun tebal dan menggelembung pada bagian tengahnya. Teksturnya agak keras dan renyah ketika dimakan. Warnanya putih kecokelatan. Bahan dasar membuat emping jet adalah singkong. Bahan tambahannya yaitu garam, penyedap rasa, bawang putih, dan minyak goreng. Cara pembuatannya, pertama singkong dikupas dan dicuci hingga bersih. Kemudian, singkong direbus dengan air hingga matang, setelah matang angkat singkong kemudian ditumbuk. Ketika ditumbuk, tambahkan bumbu halus yaitu garam, penyedap rasa dan bawang putih secukupnya. Setelah ditumbuk, adonan kemudian diselep hingga menghasilkan adonan yang lebih lembut lagi. Kemudian, adonan dibentuk dengan cara dipencet dengan jempol tangan sehingga membentuk adonan pipih seukuran Ibu jari. Lakukan itu hingga adonan habis. Setelah adonan dibentuk semua, kemudian adonan dijemur dengan rigen dibawah sinar matahari hingga kering. Setelah kering adonan siap digoreng dengan minyak panas. Tunggu hingga adonan mengembang dan matang merata. Setelah matang, angkat emping jet dan ditiriskan. Cara penyajian, emping jet disajikan bisa dalam keadaan hangat maupun dingin. Biasanya dimasukkan dalam toples maupun plastik agar tidak mlempem. Cara makan, emping jet dapat dimakan secara langsung tanpa tambahan bumbu lainnya. Emping jet dapat dijadikan sebagai makanan pendamping saat makan besar seperti soto, rawon, sega brongkos, dan sebagainya karena memiliki rasa yang gurih dan nikmat. Emping jet ketika dimakan langsung lebih nikmat sambil minum teh hangat atau kopi. Fungsi jajanan, untuk camilan biasa, untuk pacitan acara tahlilan, yasinan, arisan, oleh-oleh, dan sebagainya.

\section{Cara Kerja Prototipe}

Rancang Bangun

Langkah awal penyusunan aplikasi Jajananku adalah merencanakan tujuan. Adapun tujuannya adalah untuk memudahkan masyarakat umum dan masyarakat Jawa Tengah pada khususnya dalam mencari informasi mengenai jajanan tradisional Jawa Tengah khususnya se-Karesidenan Kedu dengan membaca nama jajanan maupun dengan melihat gambar jajanan tradisional Jawa Tengah yang termuat dalam sebuah aplikasi berbasis android.

Langkah kedua adalah melakukan pengumpulan data berupa nama jajanan, bahan dasar, pengolahan makanan (resep makanan dan cara pemasakan), cara penyajian, dan fungsi jajanan tradisional (fungsi makanan sebagai ungkapan ikatan sosisal, makanan sebagai ungkapan solidaritas kelompok, makanan dan ketegangan jiwa, simbolisme makanan dalam bahasa). 
Arif Nugroho/ Piwulang 7 (2) (2019)

Langkah ketiga, yaitu mengolah data penelitian dengan menyusun data sesuai dengan kebutuhan dan desain aplikasi Jajananku. Untuk memudahkan pengguna dalam mencari informasi, maka data disusun secara runtut, yaitu mulai dari bahan dasar, gambar jajanan, nama jajanan, deskripsi, pengolahan makanan (resep makanan dan cara pemasakan), cara penyajian, dan fungsi jajanan tradisional (fungsi makanan sebagai ungkapan ikatan sosisal, makanan sebagai ungkapan solidaritas kelompok, makanan dan ketegangan jiwa, simbolisme makanan dalam bahasa).

Langkah selanjutnya adalah mengalihbahasakan seluruh data tertulis. Pada mulanya peneliti mendapatkan data wawancara dengan bahasa campuran, yaitu bahasa Jawa dan bahasa Indonesia. Kemudian, peneliti melakukan pengolahan data dengan mentranskrip rekaman wawancara ke dalam bahasa Indonesia pada keseluruhan data ke dalam tulisan. Setelah itu, data tulisan bahasa Indonesia dialihbahasakan menjadi bahasa Jawa. Hal ini sesuai dengan tujuan awal penelitian yang ingin menggunakan dwi bahasa, yaitu bahasa Jawa dan bahasa Indonesia.

\section{Perancangan Sistem}

Setelah semua data lengkap selanjutnya peneliti membuat sebuah rangkaian sistem jalannya aplikasi dimulai dari tampilan awal berupa logo aplikasi, kemudian menuju menu pilih bahasa dan menu tentang aplikasi, kemudian setelah memilih menu bahasa akan muncul menu utama yaitu daftar bahan dasar yang terdiri dari gambar dan keterangan gambar, setelah memilih bahan dasar kemudian akan muncul tampilan daftar jajanan berdasarkan bahan dasar tersebut berupa gambar jajanan dan keterangan gambar, selanjutnya setelah memilih jajanan tradisional yang tersedia pada daftar maka akan masuk ke tampilan deskripsi jajanan yang selanjutnya pada tampilan terakhir adalah proses pengolahan makanan, dan untuk kembali ke menu awal tersedia tombol kembali. Rangkaian di atas akan menjadi alur yang baik dan jelas setelah digambarkan dan diberikan penjelasan dengan baik.

\section{Cara Pengoperasian Aplikasi Jajananku}

Pembahasan yang pertama adalah alur informasi jajanan tradisional dengan pilihan bahasa yaitu bahasa Indonesia dan bahasa Jawa. Cara pengoperasiannya sebagai berikut.
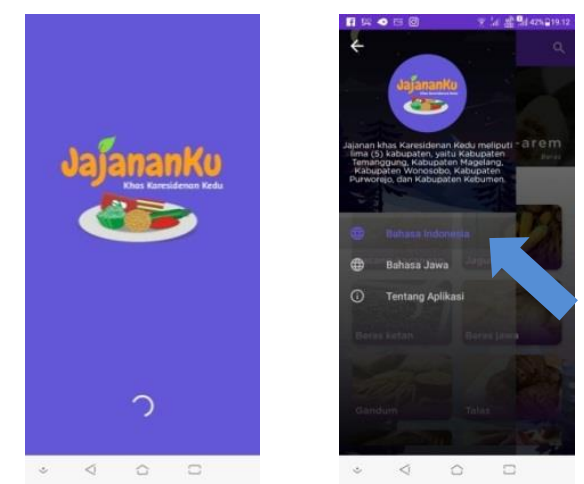

Gambar 2. Tampilan awal dan menu pilih bahasa

Pada gambar 2 di atas merupakan tampilan awal aplikasi Jajananku se-Karesidenan Kedu. Pada tampilan awal terdapat identitas dari aplikasi Jajananku. Kemudian, untuk melanjutkan pada langkah berikutnya terdapat menu pilih bahasa yaitu bahasa Indonesia, bahasa Jawa, dan tentang aplikasi. Setelah pengguna menekan salah satu menu bahasa tersebut, kemudian alur 
Arif Nugroho/ Piwulang 7 (2) (2019)

berikutnya adalah masuk pada menu utama seperti gambar berikut.

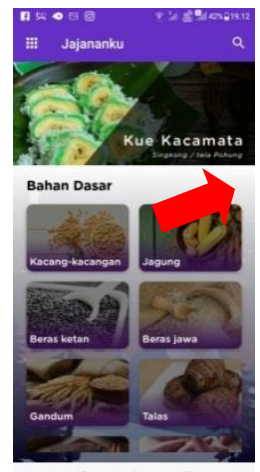

Gambar 3. Menu utama bahan dasar

Pada gambar 3 di atas merupakan tampilan menu utama yang langsung menuju pada bahan dasar. Terdapat delapan menu bahan dasar yang tersedia yaitu kacang-kacangan, jagung, beras ketan, beras jawa, gandum, kimpul, singkong, dan ubi jalar. Pengguna akan memilih salah satu dari menu yang tersedia, setelah menekan salah satu menu bahan dasar maka tampilan selanjutnya adalah sebagai berikut.

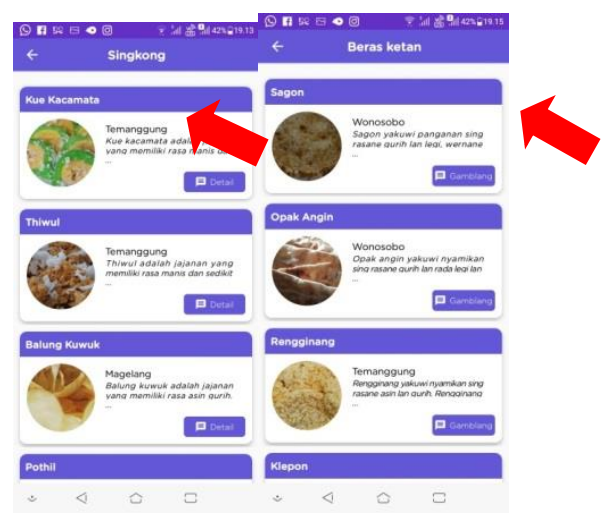

Gambar 4. Daftar Jajanan Berbahasa Indonesia dan Jawa

Pada gambar 4 tersebut tampak tampilan aplikasi berisikan daftar jajanan berbahasa Indonesia gambar sebelah kiri dan berbahasa Jawa gambar sebelah kanan. Pengguna dapat memilih sesuai keinginan dengan menggeser ke atas dan ke bawah dan untuk menuju tampilan selanjutnya adalah dengan menekan gambar bahan dasar yang tersedia dan tampilan berikutnya sebagai berikut.
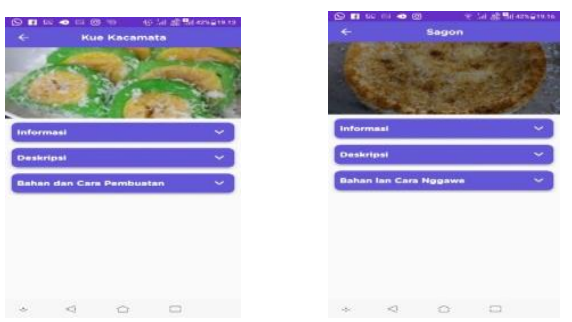

Gambar 5. Tampilan Jajanan berbahan dasar beras jawa dan singkong

Pada gambar 5 merupakan tampilan jajanan berbahan dasar beras jawa berbahasa Indonesia sebelah kiri dan bahan dasar singkong berbahasa Jawa sebelah kanan. Pada tampilan ini dapat digeser ke atas dan ke bawah untuk membaca informasi dengan lengkap dan sesuai yang tersedia dalam aplikasi ini dengan tampilan sebagai berikut.
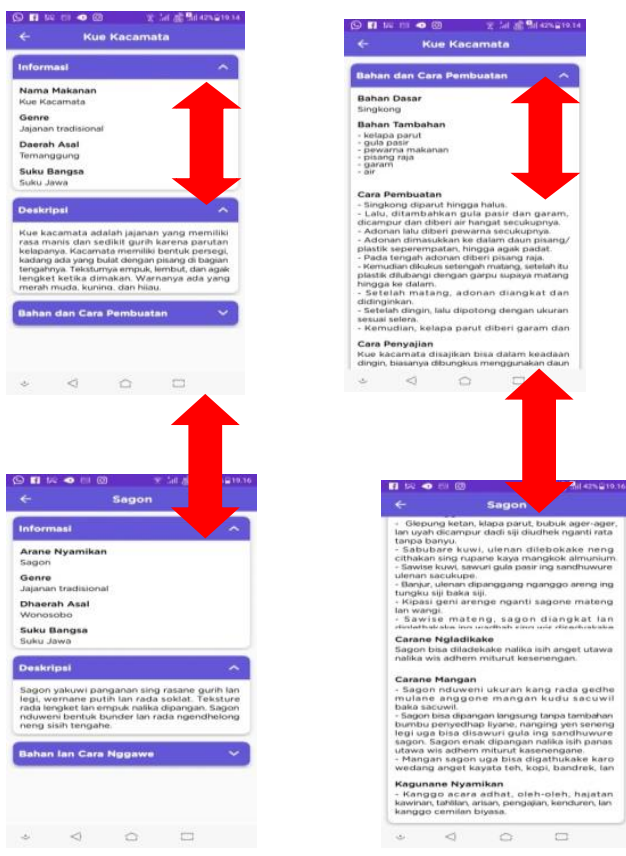

Gambar 6. Tampilan deskripsi dan cara pembuatan jajanan 
Arif Nugroho/ Piwulang 7 (2) (2019)

Pada gambar 6 merupakan tampilan deskripsi dan cara pembuatan jajanan tradisional berdasarkan data yang sesungguhnya dan telah diolah oleh peneliti. Pada gambar bagian kiri adalah tampilan dalam bahasa Indonesia dan kanan adalah tampilan dalam bahasa Jawa. Tampilan di atas berisikan deskripsi singkat dan cara pembuatan jajanan tradisional sesuai dengan gambar dan nama jajanan. Pada tampilan ini berisikan informasi mengenai bahan dasar hingga fungsi jajanan tradisional sesuai dengan kajian folklor. Kemudian untuk kembali memilih bahasa, jajanan atau bahan dasar yang diinginkan pengguna, maka pengguna dapat menekan tombol berlambangkan tanda panah ke arah kiri pada bagian kiri atas tampilan.

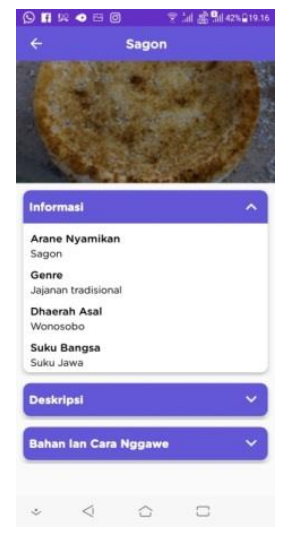

1

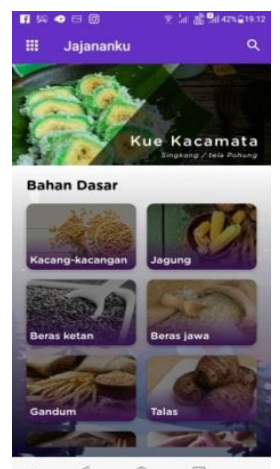

3

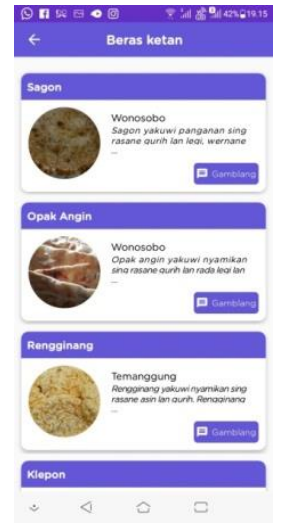

2

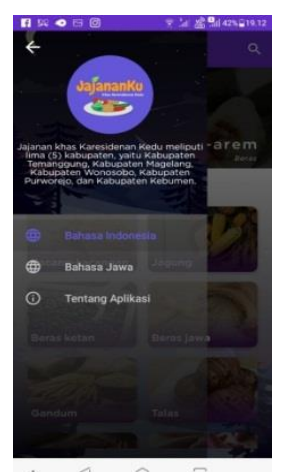

4
Gambar 7 merupakan urutan tampilan kembali menuju jajanan yang akan dipilih, bahan dasar yang akan dipilih, dan bahasa yang akan dipilih. Pada tampilan bahasa Indonesia urutan alurnya sama dengan tampilan bahasa Jawa.

Kemudian pembahasan berikutnya adalah alur yang ke dua berisikan informasi singkat mengenai aplikasi Jajananku, dan alur yang ke tiga adalah alur kembali ke awal atau keluar untuk mengakhiri penggunaan aplikasi. Pada pembahasan ini akan dideskripsikan alur penggunaan yang ke dua dengan gambar dan keterangan sebagai penjelasnya. Untuk alur yang ke dua langkah yang dilakukan pengguna tidak jauh berbeda dengan langkah alur pertama, seperti gambar berikut.

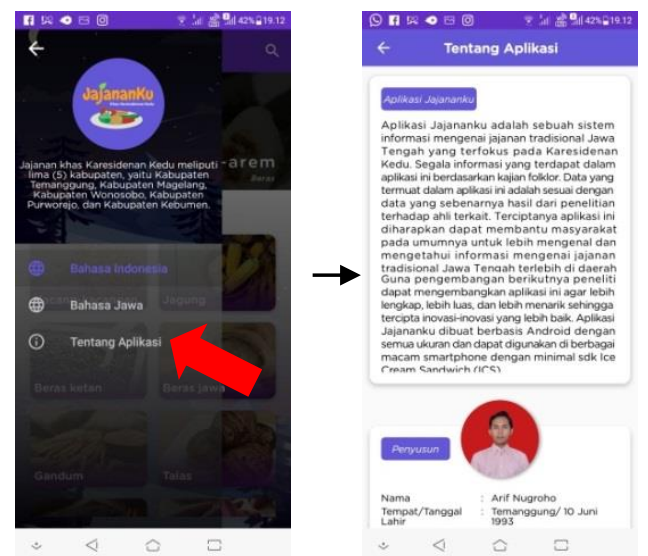

Gambar 8. Tampilan awal menu menuju tentang aplikasi

Pada gambar 8 di atas merupakan tampilan awal menu aplikasi Jajananku menuju tentang aplikasi. Pada tampilan awal menu terdapat tiga pilihan yaitu bahasa Indonesia, bahasa Jawa, dan tentang aplikasi. Pada bagian ini pengguna diarahkan untuk menekan tombol about untuk mengakses menuju tentang aplikasi. Setelah menekan tombol, maka layar yang akan muncul

Gambar 7. Urutan tampilan kembali 
Arif Nugroho/ Piwulang 7 (2) (2019)

adalah seperti pada gambar bagian kanan yaitu informasi singkat mengenai aplikasi Jajananku.

Demikianlah pembahasan mengenai cara pengoperasian aplikasi Jajananku ini Pembahasan selanjutnya adalah rumusar. masalah yang ke tiga yaitu bentuk prototipe aplikasi Jajananku sebagai sistem informasi jajanan tradisional se-Karesidenan Kedu berbasis android berdasarkan kajian folklor yang akan dibahas pada sub bab di bawah ini.

Bentuk Prototipe Aplikasi Jajananku

Setelah mengetahui cara penggunaan aplikasi Jajananku yang telah dibahas pada pembahasan sebelumnya, pada pembahasana selanjutnya adalah mengenai bentuk prototipe aplikasi Jajananku sebagai sistem informasi jajanan tradisional se-Karesidenan Kedu berbasis android berdasarkan kajian folklor. Pembahasan bentuk prototipe aplikasi Jajananku akan mendeskripsikan bagian-bagian secara mendetail dalam aplikasi Jajananku.

Sesuai dengan tujuan awal dari perancangan aplikasi Jajananku yang berbasis android dan berdasarkan kajian folklor, maka aplikasi dapat dideskripsikan sebagai berikut.

Aplikasi Jajananku adalah aplikasi yang dirancang untuk dapat digunakan pada smartphone masa kini dengan batasan terendah yang dapat menggunakan adalah smartphone dengan IOS Ice Cream Sandwich (ICS). Bentuk dasar dari aplikasi ini sudah dalam bentuk (apk) dengan ukuran $4 \mathrm{Mb}$, sehingga bisa langsung diinstal pada smartphone pengguna dengan mudah. Kemudian untuk bentuk tampilan isi dari aplikasi adalah sebagai berikut.
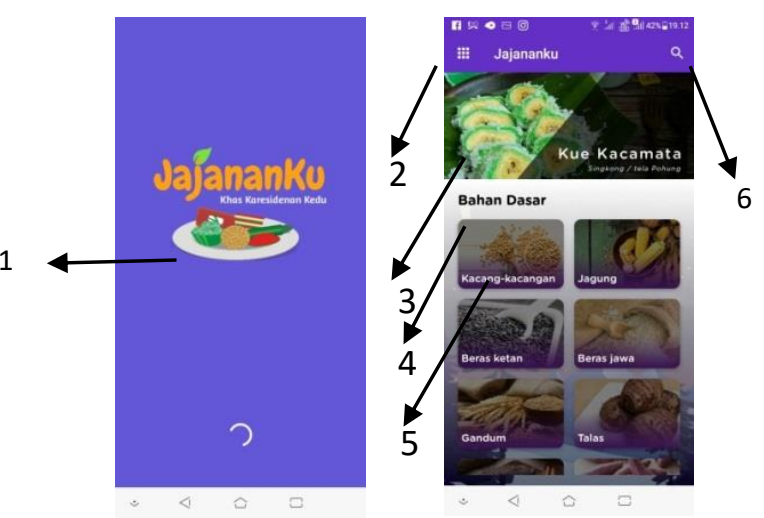

Gambar 9. Tampilan awal masuk aplikasi Jajananku

Pada gambar 9 adalah tampilan awal ketika masuk pada aplikasi Jajananku dengan beberapa fungsi tombol dan dengan tampilan berupa keterangan-keterangan mengenai aplikasi Jajananku. (1) Logo aplikasi Jajananku otomatis pada tampilan, (2) tombol menu utama yang akan menampilkan menu pilih bahasa dan tentang aplikasi, (3) ilustrasi gambar jajanan tradisional, (4) keterangan menu bahan dasar, (5) tombol bergambar bahan dasar jajanan tradisional, (6) tombol pencarian. Kemudian pada tampilan berikutnya adalah setelah menekan tombol nomor dua (2) sebagai berikut.

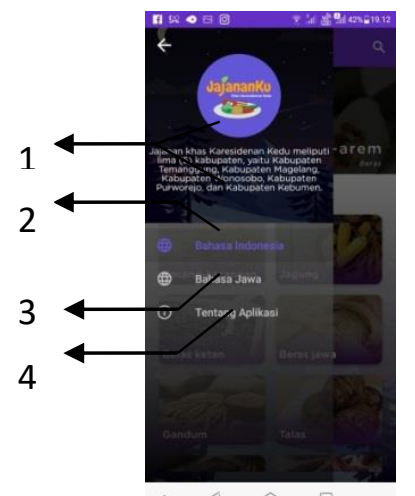

Gambar 10. Tampilan menu utama

Pada gambar 10 adalah tampilan menu utama dengan tiga pilihan yang tersedia yaitu pilihan bahasa Indonesia, bahasa Jawa, dan tentang 
Arif Nugroho/ Piwulang 7 (2) (2019)

aplikasi. Pada tampilan ini nomer (1) adalah kolom logo dan teks singkat tentang aplikasi, (2) adalah pilihan bahasa Indonesia di mana setelah memilih bahasa Indonesia maka informasi mengenai jajanan tradisional akan tersaji menggunakan bahasa Indonesia, (3) adalah pilihan bahasa Jawa di mana setelah memilih bahasa Jawa maka informasi mengenai jajanan tradisional akan tersaji menggunakan bahasa Jawa, (4) adalah pilihan menu tentang aplikasi yang berisikan informasi singkat mengenai aplikasi Jajananku. Tampilan pada bagian selanjutnya baik dari bahasa Indonesia maupun bahasa Jawa adalah sama, hanya bahasanya saja yang membedakan, maka untuk membahasnya peneliti akan menampilkan salah satunya agar lebih efisien sebagai berikut.

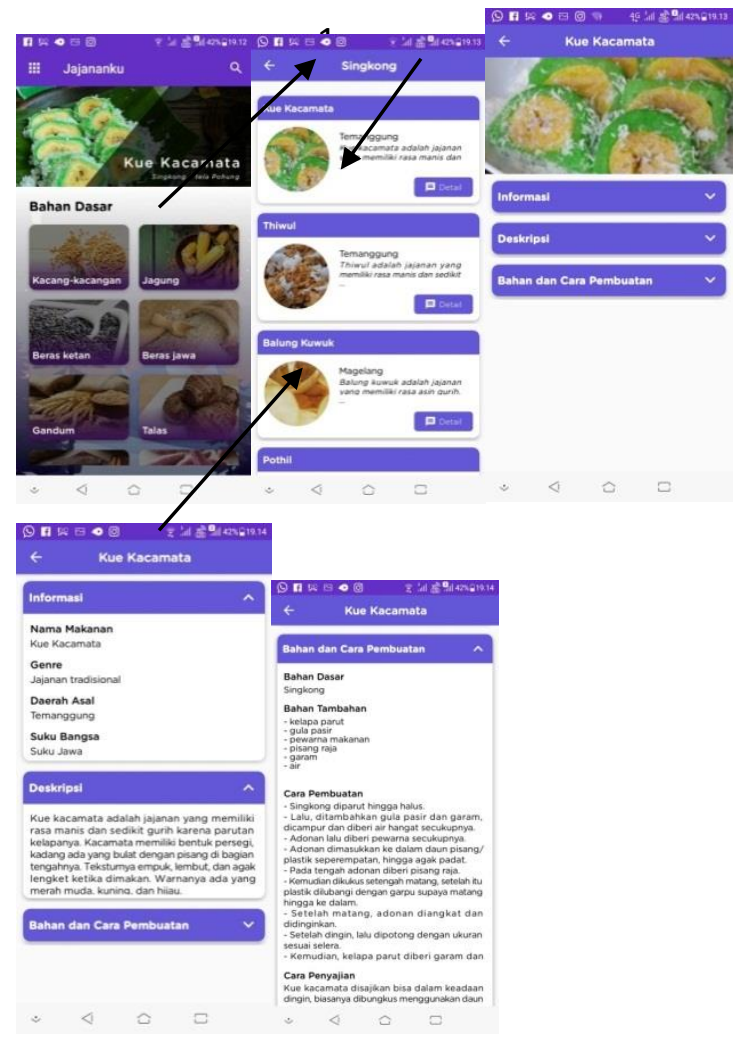

Gambar 11. Tampilan daftar bahan dasar hingga cara pembuatan jajanan
Pada gambar 4.60 di atas adalah tampilan daftar bahan dasar jajanan tradisional hingga cara pembuatan jajanan dengan penjelasan nomor (1) adalah menunjukkan tampilan menu bahan dasar ditunjukkan dengan gambar dan keterangan yang berfungsi sebagai tombol untuk menuju jajanan dengan bahan dasar sesuai gambar, (2) adalah tampilan gambar dan keterangan dari gambar mengenai macammacam jajanan tradisional dan berfungsi sebagai tombol menuju halaman selanjutnya yaitu deskripsi dan cara pembuatan jajanan, (3) nama atau identitas jajanan sesuai dengan gambar dan informasinya, (4) adalah deskripsi dari jajanan tradisional dan cara pembuatan jajanan, (5) identitas jajanan tradisional sesaui dengan hasil penelitian dan akta yang ada, (6) tombol kembali untuk menuju menu awal.

\section{SIMPULAN}

Terdapat lima puluh macam jajanan tradisional se-Karesidenan Kedu yang dikaji berdasarkan kajian folklor dan visibel kemudian telah diolah sesuai dengan kebutuhan sehingga dapat dimuat dalam aplikasi Jajananku. Cara kerja aplikasi Jajananku dapat dengan mudah dijalankan oleh pengguna dan alur rancang bangun sesuai dengan harapan penyusun sekaligus peneliti, sehingga tidak menyulitkan pengguna dalam mengoperasikan aplikasi Jajananku. Aplikasi Jajananku dapat diakses oleh platform android minimal pada sdk Ice Cream Sandwich (ICS) dan berukuran $4 \mathrm{Mb}$. Aplikasi ini berisikan informasi mengenai jajanan tradisional berdasarkan kajian folklor dan bentuk dari aplikasi Jajananku sesuai dengan sasaran peneliti yaitu terciptanya aplikasi 
Arif Nugroho/ Piwulang 7 (2) (2019)

Jajananku sebagai sistem informasi jajanan tradisional se-Karesidenan Kedu berbasis android berdasarkan kajian folklor.

\section{DAFTAR PUSTAKA}

Akbar, Mohammad, dkk. 2014. Pembuatan Aplikasi Layanan Pesan Antar Makanan Pada Sistem Operasi Android. TRANSMISI. 16(4). 170-174.

Anggara, Norman, dkk. 2012. Aplikasi Resep Masakan Daerah dengan Web Service dan Facebook API Berbasis Android. Salatiga: Program Studi Teknik Informatika Fakultas Teknologi Informasi Universitas Kristen Satya Wacana.

Arikunto, Suharsimi. 2010. Prosedur Penelitian : Suatu Pendekatan Praktik - Edisi Revisi. Jakarta : Rineka Cipta.

Aristi, Widya Mariska, dkk. 2016. Pengembangan Aplikasi Resep Masakan Khas Tradisional Berbasis Android dengan Metode Rapid Application Development (RAD). Medan: Program Studi Teknik Informatika Sekollah Tinggi Teknik Harapan Medan.

Bhandge, Kirti. 2015. A Proposed System for Touchpad Based Food Ordering System Using Android Application. International Journal of Advanced Research in Computer Science \& Technology. 3 (1). 70-72.

Bhargave, Ashutosh. 2013. Digital Ordering System for Restaurant Using Android. International Journal of Scientific and Research Publications. 3 (4). 1-7.

Budi, Noor Sulistyo. 2014. Mie Des Khas Kuliner Tradisional Pundong, Bantul, Yogyakarta. Balai Pelestarian Nilai Budaya Yogyakarta. Jantra. 9(1). 29-38.

Chang ,Tony. 2012. Food Fight: A Social Diet Network Mobile Application. Universitas California.

Danandjaja, James. 2007. Folklor Indonesia - Cet. VII. Jakarta: Kreatama.

Endraswara, Suwardi. 2009. Metodologi Penelitian Folklor. Yogyakarta: MedPress.

Endraswara, Suwardi. 2013. Folklor Nusantara: Hakikat, Bentuk, Dan Fungsi. Yogyakarta : Ombak (Anggota IKAPI).
Enterprise, Jubilee. 2015. Mengenal Dasar-Dasar Pemrograman Android. Jakarta. PT Elex Media Komputindo (Anggota IKAPI).

Fadhilah, Amir. 2014. Budaya Pangan Anak Singkong dalam Himpitan Modernisasi Pangan : Eksistensi Tradisi Kuliner Rasi (Beras Singkong) Komunitas Kampung Adat Cireundeu Leuwi Gajah Cimahi Selatan Jawa Barat. Al-Turāś. XX(1). 13-30.

Hutahaean, Jeperson. 2014. Konsep Sistem Informasi. Yogyakarta: Deepublish.

Ichwan, Nur Barik, dkk. 2013. Perancangan Aplikasi Resep Masakan Khas Jawa Berbasis Android. Surakarta: Fakultas Komunikasi dan Informatika Universitas Muhammadiyah Surakarta.

Krishna, Patel.M. dkk. 2015. Automated Food Ordering System. International Journal of Engineering Research and Development (IJERD). 2278-067(X). 41- 45.

Nashuha, Akromul Hakim. 2014. Aplikasi Resep Masakan Indonesia Berbasis Android. Surakarta: Fakultas Komunikasi dan Informatika Universitas Muhammadiyah Surakarta.

Nurhayati, Endang. Dkk. 2003. Inventarisasi Makanan Tradisional Jawa Serta Alternatif Pengembangannya. Penelitian Guru Besar. Yogyakarta: Universitas Negeri Yogyakarta.

Ricky, Michael Yosep. 2014. Mobile Food Ordering Application using Android OS Platform. Jakarta. Computer Science Department. School of Computer Science. Bina Nusantara University. 68 (00041). 1-8.

Rochani, Siti. 2007. Cara Membuat Kue Serabi. Jakarta : Ganeca Exact.

Susilantini, Endah. 2014. Kuliner Tradisional Jawa dalam Serat Centhini. Jantra. 9(1). 81-92.

Sugiyono. 2013. Metode Penelitian Pendidikan: Pendekatan Kuantitatif, Kualitatif, dan R\&D. Bandung : Alfabeta. 